九州大学学術情報リポジトリ

Kyushu University Institutional Repository

\title{
Germinability of Embryos during Seed Development in Citrus (Rutaceae)
}

Wakana, Akira

Laboratory of Horticultural Science, Division of Agricultural Botany, Department of Plant Resources, Faculty of Agriculture, Kyushu University

Ngo, Binh Xuan

Laboratory of Fruit Tree Science, University Farm, Faculty of Agriculture, Kyushu University

Iwamasa, Masao

Laboratory of Fruit Tree Science, Faculty of Agriculture, Saga University

https://doi.org/10.5109/4564

出版情報: 九州大学大学院農学研究院紀要. 49 (1)，pp.49-59，2004-02-01. Faculty of Agriculture， Kyushu University

バージョン :

権利関係 : 


\title{
Germinability of Embryos during Seed Development in Citrus (Rutaceae)
}

\author{
Akira WAKANA ${ }^{1,2 *}$, Binh Xuan NGO ${ }^{2,3}$ and Masao IWAMASA ${ }^{4}$ \\ ${ }^{1}$ Laboratory of Horticultural Science, Division of Agricultural Botany, Department of \\ Plant Resources, Faculty of Agriculture, Kyushu University, \\ Fukuoka 812-8581, Japan \\ (Received October 31, 2003 and accepted November 14, 2003)
}

\begin{abstract}
Germinability during embryo development was investigated in five Citrus cultivars with different degree of polyembryony and earliness of fruit ripening. Mature embryos extracted from fruits of the five cultivars on January 15 germinated on water by 3 days after sowing (DAS). In these cultivars, germination rates of embryos from green fruits collected in the middle of September were very low, increased rapidly in those collected in the late of September and reached $100 \%$ by 3.5 DAS in those extracted in October. The increase of germination rate was different in different cultivars. In satsuma mandarin, embryos of early ripening 'Okitsuwase' was preceded in growth and germinated about two weeks faster than those of middle ripening 'Hayashi Unshiu'. 'Hassaku' embryos showed the fastest germination rate whereas highly polyembryonic 'Seminole' embryos showed the slowest rate. It was estimated from these results that embryos matured in the early of October for 'Okitsuwase', the middle of October for 'Hayashi Unshiu' and 'Hassaku', the late of October for 'Kawano Natsudaidai' and the early of December for 'Seminole. In polyembryonic mature seeds, alone and combined applications of $1 \mathrm{mg} / \mathrm{GA}$ and $20 \mathrm{mg} / \mathrm{l}$ adenine solutions increased the number of germinated embryos per seed. Germination of the immature embryos with low germinability was enhanced by light ( 3000 luxes), MS medium, adenine (10-100 mg/l), gibberellin $\left(\mathrm{GA}_{3} 1-10 \mathrm{mg} / \mathrm{l}\right)$ and combination of these factors. These results may contribute to the efficient cross breeding in Citrus.
\end{abstract}

\section{INTRODUCTION}

Most of Citrus species and cultivars have very long generation time, i.e., their juvenile periods range from 3-4 years for lime to more than 10 years for pummelo, yuzu, and their related hybrids. The delay in flowering caused by these long juvenile periods is a major problem in breeding and selection of fruit trees (Hansche, 1983). Environmental, nutritional, physical and chemical treatments are known to be effective to shorten the generation time of fruit trees with long juvenility (Hackett, 1985). Among these, paclobutrazol treatment, girdling and, especially in Japan, top work are often used to shorten the periods. In addition to these treatments, shortening of the period between seed sowing and germination is also an important factor to increase the efficiency in breeding and selection in Citrus.

\footnotetext{
${ }^{2}$ Laboratory of Fruit Tree Science, University Farm, Faculty of Agriculture, Kyushu University, Fukuoka 811-2307

${ }^{3}$ Department of Horticulture and Bio-Technology, Faculty of Plant Production, Thai Nguyen University of Agriculture and Forestry, Thai Nguyen, Viet Num.

${ }^{4}$ Laboratory of Fruit Tree Science, Faculty of Agriculture, Saga University, Saga, 850-2307, Japan

* Corresponding author (E-mail: wakana@agr.kyushu-u.ac.jp).
} 
There is no seed dormancy in Citrus because of its tropical nature. Germination of Citrus seed is hypogeal. Citrus seeds contain a large amount of lipid and are, therefore, sensitive to excessive drying (Spiegel-Roy and Goldschmidt, 1996). About 20 days are required from seed sowing to emergence at an optimum temperature of $30^{\circ} \mathrm{C}$ in mature Citrus seeds (Davies and Albrigo, 1994). In this case, removal of the seed coat results in the considerable shortening of the days required for germination. Knowing the time or date when developing Citrus embryos first start to germinate is an important key to shorten the period between pollination and seed germination. So far, no reports are informative for germinability of embryos during their growth and development in various Citrus cultivars.

In mature seeds of polyembryonic Citrus cultivars, on the other hand, the rate of appearance of zygotic seedlings per seed logarithmically decreased with increase of embryo number per seed, since the zygotic embryo is usually behind in growth and eventually looses the capability of germination (Cameron and Soost, 1968; Wakana and Uemoto, 1988). In this case, facilitation of germination of the immature embryos within the mature or immature seeds may improve the cross breeding efficiency in Citrus.

In the present study, the germination rate of embryos during seed development was firstly investigated in five representative Citrus cultivars to demonstrate the appropriate time to collect young seeds with germinability as early as possible, and the enhancement of germination of immature embryos was studied as the basis of efficient cross breeding in Citrus.

\section{MATERIALS AND METHODS}

\section{Plant materials}

Five Citrus cultivars were chosen for this experiment (Table 1). These cultivars were about 15-year-old trees grown in the orchard of Saga University, Saga.

Table 1. Citrus cultivars used.

\begin{tabular}{llll}
\hline Cultivar & Species & Ripening & $\begin{array}{l}\text { Degree of } \\
\text { polyembryony }\end{array}$ \\
\hline Okitsu Wase & C. unshiu Marc. & October & high \\
Hayashi Unshiu & C. unshiu Marc. & December & high \\
Seminole & C. paradisi $\times$ C. tangerina & April & high \\
Kawano Natsudaidai & C. natsudaidai Hayata & April & moderate \\
Hassaku & C. hassaku Hort. ex Tanaka & March & monoembryonic \\
\hline
\end{tabular}

\section{Seed germination test}

Flower buds of the five cultivars just before anthesis were pollinated with 'Kawano Natsudaidai' pollen between May 10 and 17 in 1977. Five immature green fruits were collected from each of the cultivars at intervals of 7 days from September 10 to October 29 or from about 110 to 160 days after pollination. The immature seeds with soft integuments were immediately extracted from the immature fruits and the integuments were removed with forceps to obtain embryo(s). As a control for these seeds, mature seeds 
with hard integuments were also extracted from colored fruits of the five cultivars on January 15 and then the embryos were dissected out. In each of the polyembryonic cultivars, the embryos dissected out from 25 to 40 seeds each were placed on a $15 \times 20$ $\mathrm{cm}$ lidded plastic box in which wet filter paper (Toyo No. 2) with distilled water were laid out on the bottom. In monoembryonic 'Hassaku', about 30 embryos from plump seeds were chosen for germination test, placed on wet filter paper and incubated similarly. The embryos were incubated under dark condition at $28^{\circ} \mathrm{C}$ or under light (3000 luxes) at $28^{\circ} \mathrm{C}$. Germination of the incubated embryos was examined at intervals of about 3 or 7 days. In this case, the germination was defined as the elongation of hypocotyls with the initiation of root formation in the embryos.

To certify the effect of various concentrations of gibberellin $\left(\mathrm{GA}_{3}: 0,1,10\right.$ and $100 \mathrm{mg} / \mathrm{l})$ and adenine $(0,10$ and $100 \mathrm{mg} /)$ on the facilitation of germination of immature embryos, these were applied to embryos derived from green fruits of 'Kawano Natsudaidai' on September 14 according to the procedure mentioned above. In addition, alone and combined effects of solutions of gibberellin $(1 \mathrm{mg} /)$ and adenine $(20 \mathrm{mg} / \mathrm{l})$ on the germination of underdeveloped embryos within a highly polyembryonic seeds of mature 'Hayashi Unshiu' fruits collected on December 15 were also examined at intervals of 3.5 days with or without light ( $16 \mathrm{hrs}, 3000$ luxes)

\section{Seed germination test in vitro}

Immature 'Kawano Natsudaidai' fruits collected on September 12 and 13 were immediately surface-sterilized with $70 \%$ ethanol and immature seeds were extracted from the fruits under aseptic conditions. Embryos dissected out of the seeds were placed on culture medium. The medium, a MS medium (Murashige and Skoog, 1962) modified by Murashige and Tucker (1969) for Citrus, was supplemented with $10 \mathrm{~g} / \mathrm{l}$ agar and 0,10,20 or $40 \mathrm{mg} / \mathrm{l}$ sucrose, adjusted at $\mathrm{pH} 5.8$ with $0.1 \mathrm{~N} \mathrm{NaOH}$, dispensed in a $50 \mathrm{ml}$ culture tube at a rate of $10 \mathrm{ml}$ per vessel and autoclaved at $120^{\circ} \mathrm{C}$ for 15 minutes. Immediately after the autoclaving, $\mathrm{GA}_{3}(0,1,10$ or $100 \mathrm{mg} / \mathrm{l})$ and adenine $(0,20$ or $40 \mathrm{mg} / \mathrm{l})$ were added to the medium through filtration with sterilized cellulose acetate membrane. All embryos from each seed were planted per vessel and incubated under $28^{\circ} \mathrm{C}$ with or without light (3000 luxes) conditions.

Germination of the cultured embryos and the length of root were examined at intervals of three and half days after the incubation.

\section{RESULTS}

\section{Germination of mature embryo}

Germination rate of embryos dissected out on January 15 was $100 \%$ at 3 days after sowing (DAS) on water in all cultivars examined (Table 2). Among the five cultivars, 'Seminole' tangelo showed the fastest germination rate, i.e., the embryos from $72 \%$ of seeds germinated 2 DAS. There was little difference in the germination rate of embryos of 'Kawano Natsudaidai' between dark and light conditions. Among embryos in each of polyembryonic seeds, only large ones germinated by 3 DAS and small or underdeveloped ones were unable to germinate even after the 3 DAS. 
Table 2. Germination of mature embryos collected from colored fruits of five Citrus cultivars on January 15.

\begin{tabular}{lcccrrr}
\hline \multirow{2}{*}{$\begin{array}{l}\text { Cultivar } \\
\text { Light }\end{array}$} & \multirow{2}{*}{$\begin{array}{l}\text { No. of seefs } \\
\text { examined }\end{array}$} & \multicolumn{6}{l}{$\begin{array}{l}\text { \% germination on the indicated days } \\
\text { after sowing }\end{array}$} \\
\cline { 4 - 7 } & & & 1.5 & 2.0 & 2.5 & 3.0 \\
\hline Kawano Natsudaidai & - & 25 & 0 & 12 & 100 & 100 \\
Kawano Natsudaidai & + & 25 & 0 & 0 & 100 & 100 \\
Hassaku & - & 25 & 0 & 4 & 96 & 100 \\
Hayashi Unshiu & - & 25 & 0 & 12 & 100 & 100 \\
Okitsuwase Unshiu & - & 25 & 0 & 12 & 92 & 100 \\
Seminole & - & 25 & 12 & 72 & 100 & 100 \\
\hline
\end{tabular}

${ }^{a}+: 16$ hrs, 3000 luxes; -: dark.

\section{Germination of immature embryo}

Satsuma mandarin: In the seeds of medium ripening cultivar 'Hayashi' collected on September 10, the nucellar tissue and endosperm were observed around the embryos, whereas in the seeds of early ripening cultivar 'Okitsuwase' they were almost digested by the embryos, i.e., the embryos proceeded in growth than those of 'Hayashi'. In the seeds of fruits collected at intervals of 7 days from September 9 to October 29, embryos
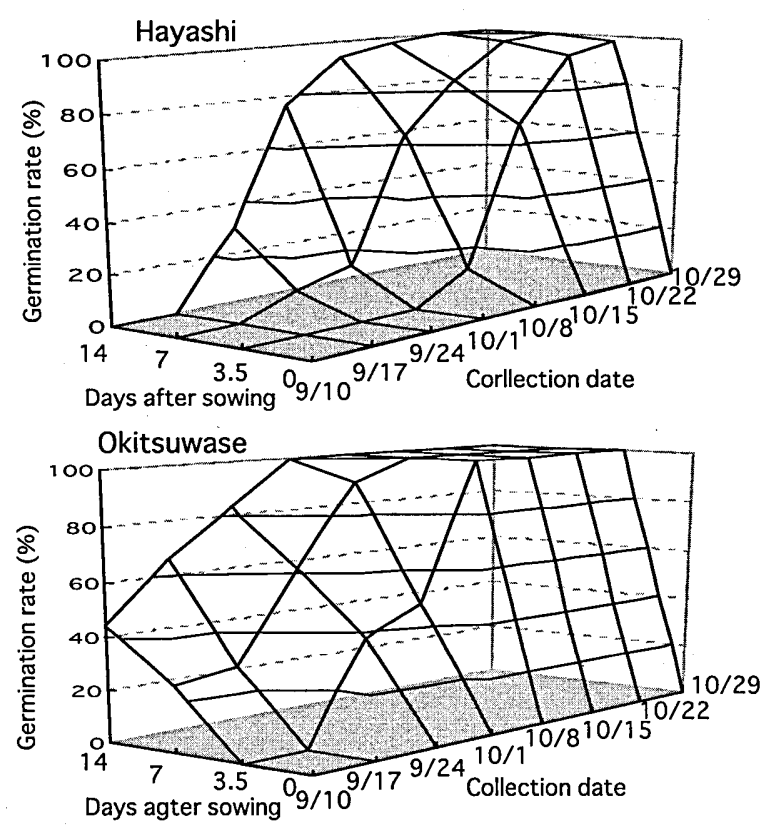

Fig. 1. Germination rates of embryos dissected out of seeds extracted from premature 'Hayashi' (upper) and 'Okitsuwase' (lower) satsuma mandarin fruits at intervals of 7 days and placed on water. 
extracted from those of 'Okitsuwase' germinated earlier and faster than 'Hayashi' (Fig. 1). Germination of embryos of 'Okitsuwase' at 3.5 DAS first commenced at those from about $40 \%$ of seeds collected on September 24, whereas in 'Hayashi' it first commenced at those from $11 \%$ of seeds collected on October 8 . Embryos from all seeds of 'Okitsuwase' collected after October 8 germinated 3.5 DAS, whereas in 'Hayashi' it was on October 29.

'Hassaku': Seeds collected on September 10 contained an embryo that digested almost of the nucellar tissue and endosperm but was not germinated by 3.5 DAS. Embryos from $12 \%$ of seeds collected on September 17 germinated 3.5 DAS and the germination rate increased slowly up to $94 \%$ by 14 DAS (Fig. 2). Embryos from $70 \%$ of seeds collected on September 24 germinated 3.5 DAS, and after this collection date germination rate at 3.5 DAS gradually increased and leached 100\% on October 15 .

'Seminole': Among the five cultivars used in this experiment, 'Seminole' tangelo showed the slowest embryo growth rate. In the seeds collected on September 10, small amount of endosperm and thin layer of nucellar tissue were observed at the chalazal part and around the embryos respectively. Germination was firstly observed 7 DAS at embryos from $3.3 \%$ of seeds collected on September 24 (Fig. 2). The germination rate in 3.5 DAS increased slowly up to October 22, and then increased rapidly. The Germination rate, however, did not leach $100 \%$ by October 29 .

'Kawano Natsudaidai': In the seeds collected on September 10, small amount of the


Fig. 2. Germination rates of embryos dissected out of seeds extracted from premature 'Hassaku' (upper) and 'Seminole' (lower) fruits at intervals of 7 days and placed on water. 



Fig. 3. Germination rates of embryos dissected out of seeds extracted from premature 'Kawano Natsudaidai' fruits at intervals of 7 days and placed on water. Upper: dark conditions; lower: light (3000 luxes, 16hrs) conditions.

nucellus and endosperm tissue was observed at the chalazal part. The embryos were slightly behind in growth as compared with those of 'Hassaku'. The first germination at 3.5 DAS occurred in the embryos from $12.5 \%$ of seeds collected on September 24, and the rate of seeds rapidly increased from October 1 to October 15 on which embryos from all seeds germinated (Fig. 3).

The germination pattern in 'Kawano Natsudaidai' resembled to that in 'Hassaku' except that germination rates at 3.5 DAS were quite low between September 17 and October 8 . Under the light conditions, these low germination rates were improved to the extent that 'Hassaku' seeds exhibited (Fig. 2).

\section{Solutions of growth regulators}

Very low Germination rates of embryos extracted from immature 'Kawano Natsudaidai' fruits on September 14 were greatly improved by the application of 10 and $100 \mathrm{mg} / \mathrm{l}$ adenine solutions and 1 and $10 \mathrm{mg} / \mathrm{GA}_{3}$ solutions (Fig. 4). Adenine solutions increased the germination rates about three times as high as the application of water. Moreover, $\mathrm{GA}_{3}$ solutions greatly increased the germination rates, i.e., they were about $35 \%$ for 3 DAS, $90 \%$ for 7 DAS and 100\% for 11 DAS. There were little differences in the germination rates between the 10 and $100 \mathrm{mg} / \mathrm{l}$ adenine solutions and between 1 and 


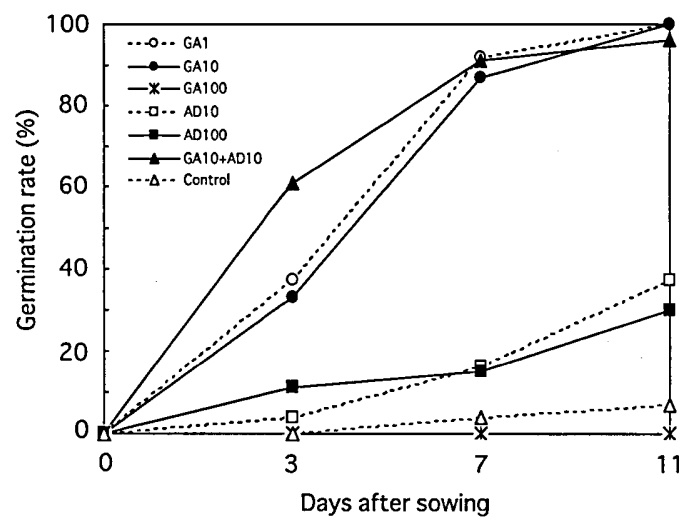

Fig. 4. Effect of alone and combined applications of gibberellin $\left(\mathrm{GA}_{3} ; 1,10\right.$ and $\left.100 \mathrm{mg} / \mathrm{l}\right)$ and adenine $(\mathrm{AD} ; 10$ and $100 \mathrm{mg} / \mathrm{l})$ on the germination of immature embryos dissected out of seeds extracted from premature 'Kawano Natsudaidai' fruits on September 14.

$10 \mathrm{mg} / \mathrm{GA}_{3}$ solutions. However, the embryos did not germinate when a high concentration $(100 \mathrm{mg} / \mathrm{l})$ of $\mathrm{GA}_{3}$ solution was applied. Application of a solution of $10 \mathrm{mg} / \mathrm{l} \mathrm{GA} 3$ and $10 \mathrm{mg} / \mathrm{l}$ adenine showed the greatest germination rate of $60 \%$ at $3 \mathrm{DAS}$, although the rate was the same as those in application of 1 and $10 \mathrm{mg} / \mathrm{l} \mathrm{GA} \mathrm{A}_{3}$ solutions at 7 DAS.

In highly polyembryonic seeds of mature 'Hayashi' fruits collected on January 15, number of embryos germinated per seed was increased by the treatment with $1 \mathrm{mg} / 1 \mathrm{GA}_{3}$ solution (Table 3 ). However, addition of $20 \mathrm{mg} / \mathrm{l}$ adenine to the $\mathrm{GA}_{3}$ solution was effective but did not enhance beyond the rate. Combined application of $1 \mathrm{mg} / \mathrm{GA} \mathrm{A}_{3}, 20 \mathrm{mg} / \mathrm{l}$ adenine and light did not show the prominent effect for the germination of multiple embryos. In these cases, germination rate of embryos was different in different embryo sizes, i.e., the embryos less than $5 \mathrm{mg}$ did not germinate but the germination rate increased with increase of the embryo size (Fig. 5). Application of a solution of $1 \mathrm{mg} / \mathrm{l} \mathrm{GA}_{3}$ to the embryos increased the germination rates in all ranges of embryo sizes from less than $5 \mathrm{mg}$ to more than $40 \mathrm{mg}$ with great increase in germination between 5 and $40 \mathrm{mg}$. Application

Table 3. Effect of alone and combined applications of $\mathrm{GA}_{3}$, adenine and light on germination of embryos dissected out of mature seeds from highly polyembryonic 'Hayashi Unshiu' fruits collected on January 15.

\begin{tabular}{ccccccc}
\hline \multicolumn{2}{c}{ Concentraton (mg/l) } & & $\begin{array}{c}\text { No. of } \\
\text { seeds }\end{array}$ & $\begin{array}{c}\text { Mean No. of } \\
\text { embryos }\end{array}$ & $\begin{array}{c}\text { Mean No. of germinated } \\
\text { embryos (\%) }\end{array}$ \\
\hline GA $_{3}$ & Adenine & Light $^{\mathrm{a}}$ & & & & \\
0 & 0 & - & & 25 & 16.00 & $3.68(23.0)$ \\
1 & 0 & - & 25 & 15.60 & $4.44(28.5)$ \\
1 & 20 & - & 25 & 15.96 & $4.04(25.3)$ \\
1 & 20 & + & 25 & 16.04 & $3.75(23.4)$ \\
\hline
\end{tabular}

a 16 hrs, 3000 luxes. -:dark. 


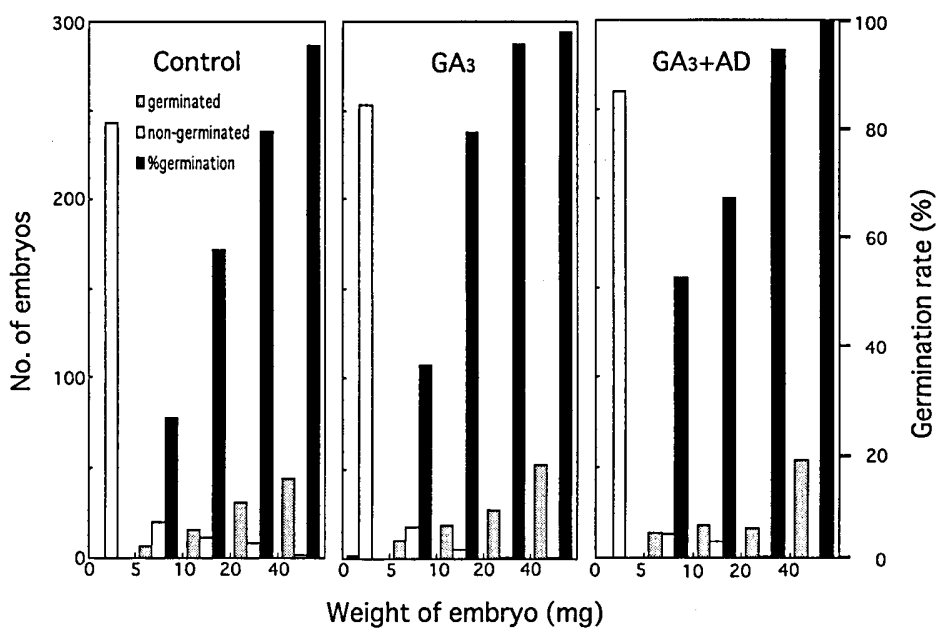

Fig. 5. Effect of solutions of $\mathrm{GA}_{3} 1 \mathrm{mg} / \mathrm{l}$ and $\mathrm{GA}_{3} 1 \mathrm{mg} / \mathrm{l}$ +adenine (AD) $20 \mathrm{mg} / 1$ on the germination of embryos dissected out of mature seeds of highly polyembryonic 'Hayashi Unshiu' satsuma mandarin fruits collected on January 15. The germination rates of embryos with different weight were examined two weeks after sowing on water.

of a solution of $1 \mathrm{mg} / 1 \mathrm{GA}_{3}$ and $20 \mathrm{mg} / \mathrm{l}$ adenine showed similar effect on the germination of embryos with the greatest increase in the germination of relatively small-sized embryos (5-10 mg).

\section{MS medium with growth regulators}

Embryos extracted from seeds of immature 'Kawano Natsudaidai' fruits collected on September 13 and 14 showed very low germination rates ( $0 \%$ for 3.5 and $8 \%$ for 7 days of culture) on agar medium without any attendants as those on water listed in Fig. 3.

Table 4. Effect of alone and combined applications of $\mathrm{GA}_{3}$ and adenine on in vitro germination of immature 'Kawano Natsudaidai' embryos derived from premature green fruits on September 13 and 14 and cultured on MS medium with $20 \mathrm{~g} / \mathrm{l}$ sucrose.

\begin{tabular}{ccccc}
\hline $\begin{array}{c}\text { Adenine } \\
(\mathrm{mg} / \mathrm{l})\end{array}$ & \multicolumn{4}{c}{ Germination rate (\%) in indicated concentration of $\mathrm{GA}_{3}(\mathrm{mg} / \mathrm{l})$} \\
\cline { 2 - 5 } & 0 & 1 & 5 & 10 \\
\hline 0 & $26.1^{\mathrm{a}}(45.5)^{\mathrm{b}}$ & $68.0(75.0)$ & $86.4(90.5)$ & $82.4(87.5)$ \\
20 & $44.0(72.0)$ & $86.9(95.6)$ & $100(100)$ & $100(100)$ \\
40 & $36.0(72.2)$ & $91.3(100)$ & $96.0(96.0)$ & $75.0(79.3)$ \\
\hline
\end{tabular}

Germination rates of embryos cultured on agar medium without addition of additives were $0 \%$ for 3.5 days of culture, and $8.0 \%$ for 7 days of culture. ${ }^{\mathrm{a}}$ Germination rate (\%) for 3.5 days of culture, and ${ }^{\mathrm{b}}$ that for 7 days of culture. 
Embryos from 26\% of the immature seeds germinated on basal MS medium with $20 \mathrm{~g} / \mathrm{l}$ sucrose by 3.5 days of culture (Table 4 ). Addition of $\mathrm{GA}_{3}$ to the basal medium increased the rate about three times as high as that on the basal medium in all of three concentrations among which $5 \mathrm{mg} / 1 \mathrm{GA}_{3}$ showed the highest rate of germination. Addition of adenine to the basal medium also increases the rate about one and half times as high as that on the basal medium in two (20 and $40 \mathrm{mg} / \mathrm{l}$ ) concentrations. Little difference was found in the rate between the two concentrations. Embryos from all seeds germinated by 3.5 days of culture when $20 \mathrm{mg} / \mathrm{l}$ adenine and 5 or $10 \mathrm{mg} / \mathrm{GA}_{3}$ were simultaneously added to the medium.

On MS medium supplemented with $1 \mathrm{mg} / \mathrm{l} \mathrm{GA}$ and $20 \mathrm{mg} / \mathrm{l}$ adenine, embryos of all immature seeds collected on September 14 germinated by 3.5 days of culture when sucrose was not added to the medium (Table 5). However, the germination rate of immature seeds, from which embryos were extracted and examined on the medium, decreased with the increase of sucrose concentration from 10 to $40 \mathrm{~g} /$. In this case, the root length was the highest in the medium supplemented with $10 \mathrm{mg} / \mathrm{l}$ sucrose and the lowest in that without sucrose.

Table 5. Effect of sucrose concentration on the germination of immature 'Kawanonatsudaidai' embryos extracted on September 14 and cultured on MS medium supplemented with $1 \mathrm{mg} / \mathrm{GA}_{3}$ and $20 \mathrm{mg} / \mathrm{l}$ adenine.

\begin{tabular}{|c|c|c|c|c|c|c|}
\hline \multirow{2}{*}{$\begin{array}{l}\text { Concentration } \\
(\mathrm{mg} / \mathrm{l})\end{array}$} & \multirow{2}{*}{$\begin{array}{c}\text { No. of } \\
\text { seeds } \\
\text { examined }\end{array}$} & \multicolumn{3}{|c|}{$\begin{array}{l}\text { Germination rate (\%) in } \\
\text { indicated days after sowing }\end{array}$} & \multicolumn{2}{|c|}{$\begin{array}{l}\text { Root length (mm) in } \\
\text { indicated days after sowing }\end{array}$} \\
\hline & & 3.5 & 7 & 10.5 & 3.5 & 7 \\
\hline 0 & 40 & 100 & - & - & 3.5 & 4.5 \\
\hline 10 & 40 & 95 & 100 & - & 5.3 & 8.8 \\
\hline 20 & 40 & 90 & 95 & 100 & 3.2 & 8.0 \\
\hline 40 & 40 & 60 & 85 & 95 & 1.8 & 7.6 \\
\hline
\end{tabular}

${ }^{a}$ Average length of roots in germinated embryos. An embryo with the longest root among germinated embryos from one seed was measured and used for calculation.

\section{DISCUSSION}

Because Citrus seeds belong to a group of recalcitrant seeds without any requirement for drying and do not have dormancy, the embryos dissected out of the seeds taken from the fruits during development and placed on water germinate when they have germinability. Irrespective of the difference in ripening times of the five Citrus cultivars chosen in this study, embryos derived from the fruits collected on January 15 and placed on water germinated up to 3 DAS. This result indicates that the embryos of the five cultivars have matured before January 15 .

In the early to middle of September, young embryos of the five cultivars first became able to germinate with a long delay or lag period. The lag period became progressively shorter and they germinated within 3.5 days between the early October and the early 
December. In these cases, the lag period was 5 to 6 weeks in all cultivars. Hence, it was estimated from these results that embryos matured in the early of October for 'Okitsuwase', the middle of October for 'Hayashi Unshiu' and 'Hassaku', the late of October for 'Kawano Natsudaidai' and the early of December for 'Seminole. The embryo germination rate proceeded in early ripening cultivars such as 'Okitsuwase' and those with large seeds such as 'Hassaku'. These may be related to the earlier accumulation and larger amount of storage substances in 'Okitsuwase' and 'Hassaku', respectively.

The lag period or slow rate of germination in the immature embryos was shortened by light, adenine, $\mathrm{GA}_{3}$ and basal MS medium, but was not by sucrose. The light did not effect on the germination of the underdeveloped and small embryos within mature polyembryonic seeds but was effective for immature embryos with slow germination rates. Although the detailed mechanism of the effect is not clear at present, photosynthesis in the immature embryos may act on enhancement of germination through activation of the metabolism related to germination.

Orsan and Cameron (1968) have been reported that in in vitro culture of immature embryos dissected out of mature seeds of highly polyembryonic 'Ponkan' development of small $(1-3 \mathrm{~mm})$ embryos on medium with $2 \%$ sucrose is better than with $1 \%$, whereas addition of $1 \%$ sucrose is better for the medium-sized ( $4-5 \mathrm{~mm}$ ) embryos. Similarly, Ohta and Furusato (1957) suggested that addition of sucrose to culture medium retarded the growth and germination of embryos more than $3 \mathrm{~mm}$. In the present study, sucrose added to MS medium was not effective on germination of immature embryos with very slow germination rates, but was available for root growth after the germination. Hence, addition of sucrose at a concentration of $10 \mathrm{mg} / \mathrm{l}$ or less is considered to be useful for production of sound seedlings, when immature embryos with very slow germination rates are cultured.

Effect of adenine on rooting of Citrus embryos cultured in vitro was firstly reported by Maheshwari and Rangaswany (1957). Kochiba et al. (1974) reported that in vitro alone and combined applications of adenine sulfate and $\mathrm{GA}_{3}$ stimulated the rooting of embryoids derived from ovule culture of 'Shamouti' orange but synthetic auxins did not. Our results also indicates that germination of immature embryos with the very slow germination rate is promoted by treatments with adenine and/or $\mathrm{GA}_{3}$, and that in vitro culture of the immature embryos on the MS medium supplemented with the two regulators has the best effect on the germination.

These results on germination of immature embryos suggests that the lack of germinability and existence of the lag period in immature embryos are due to scarcity of nutrients, low concentration of growth regulators, and the presence of germination inhibitors in the seeds: ABA has been isolated from immature seeds of many species, in which negative correlations between $\mathrm{ABA}$ content and germinability of the developing embryos are indicated, i.e., $\mathrm{ABA}$ is a factor that prevents the embryo from passing directly from embryogenesis to germination without an intervening rest period (see review by Bewley and Black, 1994). In in vitro culture of ovules of polyembryonic Citrus, low concentration $(0.002-0.25 \mathrm{mg} / \mathrm{l})$ of ABA enhanced the embryo growth but inhibit germination of resultant developed embryos (Wakana, 1985). Although we did not detect the ABA content in the immature embryos, the data and references at hand support that $\mathrm{ABA}$ is one of the major factor to inhibit germination in immature Citrus embryos. 
In the present study, we presented the information of germination in immature embryos of Citrus. This will be available for production of seedlings as early as possible in breeding and research, and contribute to zygotic embryo rescue in premature stage of embryo development in polyembryonic Citrus.

\section{REFERENCES}

Bewley, J. D. and M. Black 1994 Seeds: physiology of development and germination. Plenum Press, New York

Cameron, J. W. and H. B. Frost 1968 Genetics breeding and nucellar embryony, In "The Citrus Industry", vol. 2, ed. by W. Reuther, H. J. Webber, and L. D. Batchelor, Calif. Univ. Press, Riverside, pp. $325-370$

Davies, F. S. and Albrigo, L. G. 1994 Citrus. CAB International, Wallingford (England)

Hackett, W. P. 1985 Juvenility, maturation, and rejuvenation in woody plants. Annual Review of Plant Breeding, 7: 109-155

Hansche, P. E. 1983 Response to selection. In "Methods of Fruit Breeding", ed. by M. J. Moore and J. Janick, Purdue Univ. Press, West Lafayette, pp. 154-171

Kochiba, J. J., P. Button, P. Spiegel-Roy, C. H. Bornman and M. Kochiba 1974 stimulation of rooting of Citrus embryoids by gibberellic acid and adenine sulphate. Annals of botany, 38: 795-802

Maheshwari, P. and N. Rangaswany 1957 Polyembryony and in vitro culture of embryos of Citrus and Mangifera. Ind. J. Hort., 15: 375-382

Murashige, T. and F. Skoog 1962 A reviced medium for rapid growth and bioassays with tobacco tissue cultures. Physiol. Plant., 15: 473-497

Murashige, T. and D. P. H. Tucker 1969 Growth factor requirements of citrus tissue culture, In "Proc. 1st Int. Citrus Symp.", vol. 3, ed. by H. D. Chapman, pp. 1155-1161

Ohta, Y. and K. Furusato 1957 Embryo culture in Citrus. Rept. Kihara Inst. Biol. Res., 8: 49-54

Orsan, M. and J. W. Cameron 1963 Artificial culture of small embryos and evidence against nucellar embryony in highly zygotic varieties. Proc. Amer. Soc. Hort, Sci., 82: 210-216

Spiegel-Roy, P. and E. E. Goldschmidt 1996 Biology of Citrus. Cambridge Univ. Press, Cambridge (England).

Wakana, A., and S. Uemoto 1988 Adventive embryogenesis in Citrus (Rutaceae). Postfertilization development. Amer. J. Botany, 75: 1031-1047

Wakana, A. 1985 Enhancement of the development of immature nucellar embryos within unfertilized and undeveloped seeds in satsuma mandarin. Research Memories of Univ. Farm, Fac. Agr. Kyushu Univ., 7: 38-43 (in Japanese) 